\title{
CLEC7A wt Allele
}

National Cancer Institute

\section{Source}

National Cancer Institute. CLEC7A wt Allele. NCI Thesaurus. Code C122762.

Human CLEC7A wild-type allele is located in the vicinity of $12 \mathrm{p} 13.2$ and is approximately $13 \mathrm{~kb}$ in length. This allele, which encodes C-type lectin domain family 7 member A protein, is involved in phagocytosis and in the inflammatory response. Mutations in this gene are associated with autosomal recessive familial candidiasis 4. 